\title{
Wordsworth and Nigerian Poetry: Niyi Osundare as a Case in Point
}

\section{Kola Eke}

\section{(2) OpenEdition}

12 Journals

Electronic version

URL: https://journals.openedition.org/ces/8439

DOI: $10.4000 /$ ces.8439

ISSN: 2534-6695

\section{Publisher}

SEPC (Société d'études des pays du Commonwealth)

\section{Printed version}

Date of publication: 1 April 2010

Number of pages: 111-122

ISSN: 2270-0633

\section{Electronic reference}

Kola Eke, "Wordsworth and Nigerian Poetry: Niyi Osundare as a Case in Point", Commonwealth Essays and Studies [Online], 32.2 | 2010, Online since 18 December 2021, connection on 31 January 2022. URL: http://journals.openedition.org/ces/8439; DOI: https://doi.org/10.4000/ces.8439

\section{(c) (1)}

Commonwealth Essays and Studies is licensed under a Licence Creative Commons Attribution - Pas d'Utilisation Commerciale - Pas de Modification 4.0 International. 


\section{Wordsworth and Nigerian Poetry: Niyi Osundare as a Case in Point}

This paper raises the question of the place of "romantic theory" in African literature. It notably interrogates the ideas that lie behind Wordsworth's theories about poetic subjects and poetic language, as well as their place and meaning in an African setting. The essay examines Osundare's statements on the art of poetry and considers the (af)filiation with Wordsworth's stances. It focuses on the resonances between Osundare's Songs of the Market Place and A Nib in the Pond, among other collections, and Wordsworth's Lyrical Ballads, notably in the depiction of rustic subjects and rustic diction. The paper argues that Osundare portrays ordinary subjects, but does not systematically deploy ordinary language.

7 he Nigerian poet, Niyi Osundare, was born in Ikere-Ekiti in 1947. He attended Amoye Grammar School, Ikere, and Christ's School, Ado-Ekiti. He proceeded to the University College (now University of Ibadan), where he obtained his B.A. (Hons) in English. He obtained his M.A. from Leeds University, and Ph.D. from York University, Toronto. His poetry is very popular in Africa and beyond, and over the past three decades, he has won many honours and awards. He was notably awarded the Association of Nigeria Authors (ANA) poetry prize in 1986, and the Cadbury poetry prize in 1989. In 1986 and 1988, his poetry collections got honourable recognition from the Noma Award; and he was joint overall winner of the 1986 Commonwealth poetry prize (and at the same time active as a professor of English at the University of Ibadan, Nigeria).

The date 1798, the year of the first volume of William Wordsworth's Lyrical Ballads, marks a watershed in English literary theory. Those who are acquainted with Wordsworth's prefaces of 1798, 1800, and 1802 will not deny the huge import of these texts. In the prefaces, Wordsworth theorizes about the relationship between poetry and science, on the relationship between man and nature, on the use of metre in poetry, on the place of pleasure in art, on Aristotle, on the history of poetry, on the theme of rustic life, among others. It is undeniable that with his prefaces, Wordsworth made a great impact on poetic theory. This paper will focus on one particular aspect of romantic theory in which Wordsworth theorizes about the use of simple subjects and simple diction in poetry:

The principal object then which I proposed to myself in these poems was to make the incidents of common life interesting by tracing in them, truly though not ostentatiously, the primary laws of our nature: chiefly as far as regards the manner in which we associate ideas in a state of excitement. Low and rustic life was generally chosen because in that situation the essential passions of the heart find 
a better soil in which they can attain their maturity, are less under restraint, and speak a plainer and more emphatic language. (Wordsworth, Lyrical Ballads 245.)

This aspect of the "preface" has been increasingly recognized over the years. From the above extract one senses that most of the poems in the Lyrical Ballads are written as experiments, to try out in poetic production the use of the language of conversation of rustic people. Here Wordsworth declares himself the poet chiefly of low life. In this respect, poetry does not need aristocratic subjects; it need not deal with the high or dignified but can deal with ordinary human subjects. Therefore, the poet is not a man in the ivory tower, writing about clever emotions beyond the reach of ordinary rustics, but a man amongst men. He speaks about the essential concerns of life: love, friendship, marriage, children, death, the relation with the natural world. It is not that the feelings themselves are simple, but that the simplicity of the context makes them stand out more clearly. The poet attempts to elaborate on simple subjects because in that condition:

Our elementary feelings exist in a state of greater simplicity and consequently may be more accurately contemplated and more forcibly communicated; because the manners of rural life germinate from those elementary feelings; and from the necessary character of rural occupations are more easily comprehended; and are more durable; and lastly, because in that situation the passions of men are incorporated with the beautiful and permanent forms of nature.(Wordsworth 245).

The very notions of poetry and prose are at stake here. What distinguishes poetry from prose is, of course, not merely the language it uses, but rather how it uses language (yet even here there can be differences in language $)^{1}$. In the extract above, one can nonetheless discern a reaction to eighteenth-century conventions of (precious) poetic decorum. Working to overturn the established rules of poetry, Wordsworth challenges neoclassicism with a daring attack upon "poetic diction", demanding for poetry the "very language of men" (LB 250). He signifies that the language of poetry should not be different from the language of prose. Without reducing the issue to a question of the choice of words, he argues that simple things should be written about in simple verse. This is because the simple language is more expressive of human passions, and genuine, not artificial feelings. Wordsworth's preoccupation with simple subjects is reflected in such poems as "The Idiot Boy", "The Female Vagrant", "Simon Lee", "We Are Seven", "The Last of the Flock", "The Idle Shepherd-Boys", "Poor Susan" and "The Two Thieves", to mention but a few.

1. I am grateful to the anonymous referees for their insightful remarks and suggestions concerning the first draft of this essay, and for pointing out that it was subsequently Walt Whitman who definitely modified the idea of what kind of language was fit for poetry in the nineteenth century. My particular thanks to Marta Dvorak for the valuable comments and editorial revisions which have shaped this final version. 
This paper sets out to examine the underlying similarities between Osundare's poetic production and Wordsworth's stances (arguably part of the dialogistic "throats [poetry] plucks"; see below), but also the differences linked to their separate contexts. Osundare, too, makes out a case for the portrayal of low subjects and rustic diction in poetry. One poem, in which he sets out his poetic manifesto, cannot be appreciated in passages, but only as a whole:

Poetry is

not the esoteric whisper

of an excluding tongue

not a clap trap

for a wondering audience

not a learned quiz

Poetry is

a life spring

which gathers timbre

the more throats it plucks

harbinger of action

the more minds it stirs

Poetry is

the hawker's ditty

the eloquence of the gong

the lyric of the market place

the luminous ray

on the grass morning dew

Poetry is

what the soft wind

musics to the dancing leaf

what the sole tells the dusty path

what the bee hums to the alluring nectar

what rainfall croons to the lowering leaves

Poetry is

no oracle's kernel

for a sole philosopher's stone

Poetry

is

man

meaning

to

man. (Osundare, Songs of the Market Place, 3-4, stress added) 
This poem provides a useful illustration of Osundare's view of poetry, and can arguably be considered to be a poetic manifesto put into verse. Like Wordsworth, Osundare rebels against preciosity and obscurity, and establishes a theory of poetic simplicity. Line by line, he insists on connecting the language of poetry with rustic images, sounds, and concerns, which in no way entails a poetic impoverishment. The speaker does not hesitate to effectively deploy poetic rhetorical devices such as transference (the unusual transformation of the noun 'music' into a verb, for instance).

In "Calling a Spade", Osundare continues to show his detestation of poetic diction, insisting on rustic diction:

No needing hiding

in the tabernacle of words

so easily swept off

by the storm of anger

No need camouflaging

behind a flimsy jungle

of occult idioms...

the simple word

is the shortest distance

between two minds. (Osundare, A Nib in the Pond, 8).

Despite its complex mingling of the abstract and the concrete, despite its opposition yet mixing of the (arguably) natural and artificial through the metaphors of the tabernacle and the jungle, despite its metaphorical wordplay substituting the spaces of the mind for the clichés of geographical space, the poem rather straightforwardly calls for a simplicity of language in which the communicational function is never lost from view. I shall be looking at the notions of rusticity, urbanity, simplicity and complexity in a contemporary African context, and their convergences and divergences with the notions and terms central to Romantic/ Wordsworthian theory. I argue that Osundare does portray ordinary subjects, but does not systematically deploy ordinary language. The passages which will be considered come from the following collections: Songs of the Market Place (SMP), Village Voices (VV), A Nib in the Pond (NIP), The Eye of the Earth (TEE), and Songs of The Season (SOS).

The poem entitled "Song of the Nightsoil Man" is an interesting example of the poet's ability to transform the story of a low subject into a great poem. This is not the portrait of an aristocrat or member of a social elite, nor even of an ordinary, simple, hardworking man, but of an actor representing the lowest elements in both social and cosmological spheres. The figure mandated to collect society's basest refuse calls for an unsettling leveling equating human beings with the cloaca they all (from king to beggar) eliminate.

Dung-beetle on the road of night

I roll my forbidden burden 
Down the wasteland of life

To bury a thousand dreams

My government loves me so

And gives me a fertile job

A compost carrier at night

By day bearer of a barren purse. (NIP 35-36)

The purpose behind this poem is partly at least to excite the sympathy of the reader for the "compost carrier". One cannot fail to note the poet's admirable construction of the first-person persona, and the equally admirable use of irony to depict the speaker's social end economic predicament. It is an irony of fate that the "soilman" should work so hard, but should get a "barren purse". Here the image of infertility (ironically in opposition with the fertilizing qualities of the excrement he handles) is the most pathetically poetical display of the speaker's poverty. The discourse, with its alliteration, word play, and metaphors ('the wasteland of life' notably calling up T.S. Eliot's landmark modernist poem) is, of course, at odds with the "real" language of a rustic character. The reader encounters further gaps with the language of an ordinary "soil man":

Brimming can on head, a broom in hand

I lumber, hooded across the street

up go Mercedes windows

And children stone my stinking arse. (NIP 35)

Those who have read these lines may well ask, is this the language of a rustic labourer? Are these words coming out of the lips of a "night soil man"? Obviously, this is not the diction of a rustic. There is much in the poem that no such man could possibly say, at least in the same combination of words. Such words as "brimming", "lumber" and "hooded" appear forced, strained and 'unnatural'. Instead of employing a low register, the poet deploys a high or sublime style, making use of full alliteration (stone/stinking) and, alongside idiolectal terms such as "arse," words which can only be learned with the very pains and study he dismisses in Songs of the Marketplace. This supports the statement that in Osundare's poetry "language has become rather abstract and elitist" (Bamikunle 137). One could be tempted to conclude that Osundare writes well when he forgets his own theories about poetic diction and stops trying to prove the points he has asserted in "what poetry is." For in talking about the rigours of his profession, the persona uses a grand, affected manner in which readers can detect the overdetermining of the (critical) voice of the poet. The speaker elicits our sympathy as he tells us that he usually wears a jacket to disguise himself, that he has to move slowly because the container of human waste he carries on his head is often filled to the brim. Yet he does address us using artificially elaborate phrases. The following extract further illustrates that these are certainly not the common words which such a rustic individual would use in his daily affairs: 
'Carrier of the night porridge'

They know my praise name

Government tag is more polite

Titling me a Sanitary Engineer...

I have a hut in shanty town

And a wife and kids of eight

They know not where their daddy works

Though he spends the day in sickly sleep. (NIP 35)

The reference to the widespread derogatory euphemism equating in a carnivalesque fashion the two poles of digestion, ie ingestion (the similarly textured 'porridge') and defecation, is put in resonance with the sterile circumlocution of government terminology, ostensibly equalizing. Yet it is on a double level that the poem sets up a metatextual, intratextual dialogue with another poem in the collection, "Calling a Spade" (discussed above), for both the popular locution and the official title are periphrastic and gloss over the sordid indignities of the activity, be it considered a vocation/calling in life (coloured with inevitability and permanence), or a job/employment (coloured with the myth of an ever-accessible upward social mobility). Neither popular locution nor official title calls a spade a spade, and, on the whole, neither does the poet, inciting us rather through the oblique mode of irony to conclude that the weight of the brimming can and the lightness of the barren purse are not in sync. Although Osundare does incite us to sympathize with the rustic character, he does deploy, as nowhere else in a poem of any length, a highly elaborate poetic diction, a speech of civilized urbanity. One could draw the hasty conclusion that the poet has not yet discarded the artifices of poetic convention. Yet the elevated diction reinforces the irony of writing a poem about someone with such a job. The poem and its metaphorical "praise name" also suggests (analogous to Wordsworth's but also Emerson's stance) that poetic or figurative language does not belong only to the educated, but that it originates in the fertile imaginations of the common people. Moreover, the ironic use of government jargon (through the prism of the first-person persona) stresses the existence of different levels of language and their equally ironic discordance with social realities, and implies that the capacity to play with language or discern the discrepancies between sign and referent should not be considered as something accessible only to sophisticated, urbanized populations. It would be clearly reductive to conclude that Osundare is breaking his own poetic rules as spelt out in "calling a spade."

In another poem from the same collection, "Song of the Prostitute", Osundare uses the popular rhythm of iambic tetrameter (with a ballad-like final silent stress on alternate lines) to focus on another traditional low life figure, the prostitute:

The sun is down my wig is up it's time for the compact game A dab for wrinkles one for warts

To mask the trick of years. 
My lips are red and so is my dress

our colours shout our wares

A cigarette burns my borrowed nails

From a pack I keep for show. (NIP 38)

Osundare's audience has tended to stress the compassionate nature of the poet's portrayal of the prostitute, for a sense of complicity is automatically generated by the use of the first-person, associated with intimate subjective disclosure and endowed with a truth effect. Such readerly sympathy is reinforced by the 'biographical' details of the poem, in keeping with the conventions of melodrama, which (always) emphasize that the speaker has been forced into prostitution by circumstances beyond her control:

An orphan long before I crawled

I knew neither school nor trade

My father died in Biafra

And mother joined in grief. (NIP 38)

Readers divine that the poet's preoccupation with the predicament of an ordinary prostitute partly accounts for the sense of hidden significance which many have experienced in reading him. However, beyond the didactic dimension catalyzing sympathy for a figure generally treated as an object of disgust, what has puzzled readers is the apparent gap between low subject and poetic diction. In an analogous fashion to the strategy in "Song of the Nightsoil Man," the opening lines of the poem notably do not correspond to the manner in which an uneducated woman might speak in real life. The reader at once asks himself the crucial question, "is this the language of a low-class prostitute?" He/she can also wonder what "compact game" means. Osundare has been said to indulge in "Hopkinsian infelicities (Chinweizu et al 1973). This is because the language of the prostitute persona is that of a woman of great intellectual powers. Because the poetic passion of the prostitute is expressed in difficult and forcible language. Because the reader faces many semantic hurdles before he/she can decipher the significance of "compact game." On one level it suggests that the woman is subjecting her face and body to cosmetic treatment. On another level, it refers to the rigours and processes of prostitution. The word play is mirrored by the pun on "trick" - the sexual trick turned by the prostitute being (simultaneously and ironically) a trick played on the customer who is unaware that the alluring woman is what he would label damaged goods. The impeccable parallelism of the first line, "The sun is down my wig is up" uses simple one-syllable words to play on the equally simple notions of verticality and horizontality which characterize the world of the prostitute. But the deceptively simple concision of the antithetical parallelism calls up the conceits of Alexander Pope or the metaphysical poets, or, on the other poles of both virtuosity and temporality, the pyrotechnics of Salman Rushdie. The metonym "wig" standing for the prostitute in battle gear, or rather packaged, added to the other accoutrements of gift wrapping, e.g. red 
dress, lipstick, powder, false nails, and cigarette pack-cum-prop, together build the motif of spectacle or simulacrum. The motif is encapsulated in the term "mask" and the final word of the second stanza: "show." The "compact game" consisting of masking the potentially hideous physical defects of the prostitute (with all the connotations of underlying disease to be found in descriptions of siren figures from Homer's Circe to Spenser's female predators) also serves to mask the potentially hideous moral defects awaiting those who participate in the reification of body into ware. The diction characterized by complex layering, word play, and condensation could debatably transgress Osundare's own rule that poetry should not be a "learned quiz." It contrasts with a poem like "Song of the Houseboy" which lays down the predicament of all domestic servants in simple binary dimeters reflecting with strong ironic tension the opposite poles of the social hierarchy, such as the opening lines "I cook the meal/And eat the mess" (NIP 37). This poem illustrates the truth of the assertion that "irony may appear in poetry in three ways: in a poem's language, in its description of incident, and in its point of view" (Robert Diyanni and Kraft Rompt 40). For example, the juxtaposition of opposites such "meal" and "mess" becomes a feature of the poem: the couplet "I clean their kids/And miss my own" is echoed by "'They grow to be kings/My own to be pimps" (NIP 37). Thus this poem appears to approach far more closely that condition which Osundare describes as "man meaning to man". The vocabulary as well as syntax of some lines are such as an ordinary domestic worker would actually use. They are thus more in accordance with the poet's proclaimed poetic principles, the final couplet notably conveying a rhetorical question couched in idiolectal terms: "Is massa born to eat/And I to carry shit?" (NIP 37).

Yet the arguably artificial diction of "Song of the Prostitute" is far from being the only poem in which Osundare violates or deviates from the generally observed rules of language. The language and imagery of a poem such as "Farmer-Born" parodies Romantic poems about peasants.

Farmer-born peasant-bred

I have lived on the aroma

of fresh-felled forests

relished the delicious symmetry

of akee apple colours

and plucked the pendulous promise of ripening pawpaw. (TEE 43)

From the above lines, one can see that the ornamental element complete with alliterative devices ("fresh-felled forests") is an indispensable feature of the style, which differs vitally from that of prose, and is a glaring departure from the ordinary language of peasants. There is a sort of artificial heightening of language, which seems to be at variance with Osundare's poetic theory as stated in "what poetry is." Yet the transposition to the African context through references to "akee apple" and "paw paw"(TEE 43),for instance, is surprisingly successful, and carries the 
poem beyond the limits of pure mimicry. The Nigerian poet's praxis contradicts the poetic theory about the language of poetry, but only if one interprets poetic principles such as Wordsworth's and Osundare's in the narrowest terms. Neither Wordsworth nor Osundare were really saying that the language of poetry should in no way differ from the language of prose. They were both, however, suggesting that there is a poetic language that does not belong only to the educated, and that poetry should not be reduced to mechanical, precious word play.

Osundare actually abides by the Wordsworthian principle regarding the portrayal of a low subject. Although one cannot but support Emmanuel Ngara's statement that Osundare "devotes his poetic energies to the service of the exploited African peasantry" (177), it is clear that the speech of his persona in this poem is not a close imitation of the actual speech of a rustic (even if the "language of men" is not unconnected with beauty of style). It is rather an overcoding of somebody else's voice, the poet's. What is expressed might well be the genuine reaction of a farmer, but for which a real-life farmer might not be able to articulate. The farmer only supplies the emotional mood for which the poet finds the words. Elsewhere, as in "The New Farmer's Bank," the verbal irony in the hybridized utterance (in which the speaker's words seem to say one thing but actually mean the opposite) is more clearly discernable and of an angrier nature, eliciting sympathy for the petty farmers who need to mortgage their "livelihood" to benefit from bags of alleged institutionalized kindness:

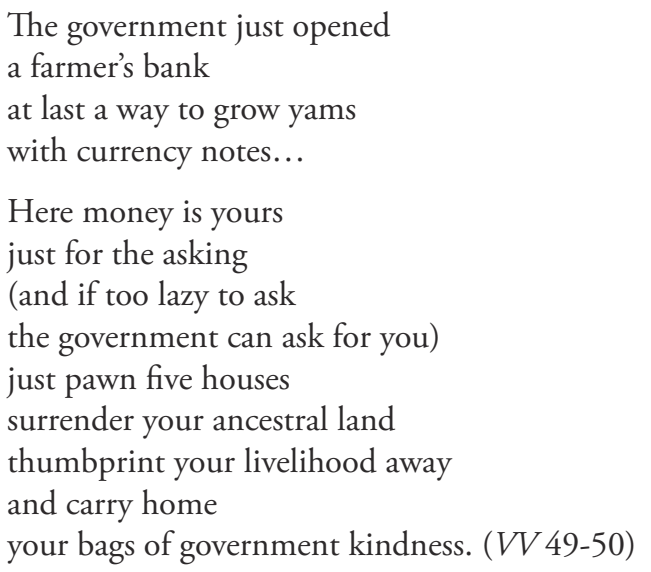

The speaker continues to express displeasure at this ugly phenomenon before concluding with a pseudo-refrain which has clearly become ironic in its conflation of banknotes and government kindness:

Then go till your land

with closed fists

how can you borrow government money

without kolatera

The government just opened 


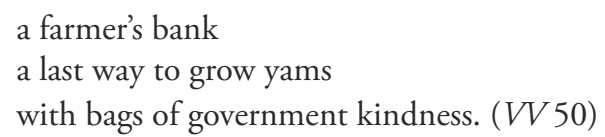

It is worth drawing attention to the word "kolateral". It is not unexpected that the rustic speaker should use "kolateral" in mistake of collateral. "Kolatera" as it occurs here emphasizes the inadequacy of language and complexity of the state of mind and feeling of the speaker. This is a most significant and interesting punning on words. The "I" of the poem has been trying to decipher the meaning of collateral. By using "kola" (from kolanut), a Nigerian euphemism for bribe, the speaker confirms his rusticity and frustration. This is a word that would be difficult for a rustic to grasp directly, and it is interesting to note how Osundare plays with it interweaving it within the difficult syntax and lexis of sentences which seem to belong to the voice of the poet.

In "Sule Chase", the poet focuses on the tragic fate of Sule, a petty thief who steals a loaf of bread from a trader's stall. By so doing, he continues to imitate Wordsworth's practice of identifying with the plight of low subjects in the Lyrical Ballads. Sule's predicament is drawn with pathos all the more powerful as it is poetically oblique, right from the initial hypallage of the man-hunt, for it is Sule (and not the afternoon) who is hungry:

The chase starts in some shadowy stall

on a hungry afternoon

"o lee barawoooooo onye oshiiiii"

Rises from tepid earth to the baking skies

A barrel-buttocked woman blows the whistle

for the fastest race in Lagos...

Forcing brothels in every street

To cough out their putrefying entrails. (SMP 16)

At this point, Sule decides to run for his dear life. The "chase" after Sule "gathers more legs/in every lane," with a list which follows the metonym, ending in exuberant alliteration:

Tailor with giant scissors

permsecs with PENDING files

Barristers with dusty wigs

NEPA experts with fused bulbs...

And Sule has

the once ina life luck

of leading Lagos in a race. (SMP 16)

Osundare portrays Sule's fate with biting humour and irony. It is a thing of laughter to see the calibre of people that are running after a petty thief. The "chase" offers a wide range of people, who like Sule, may be considered as socially unacceptable. They include seasoned prostitutes, indolent civil servants, quack 
lawyers and many others. By parading a lot of social misfits, the poet tries to tell us that Sule is better than those running after him. Pathos mounts as Sule "climbs mountains of fresh assorted garbage" and "Traverses valleys of liquefied stench", tearing through traffic, to culminate in ferocious social satire when, hours later, the Homicide unit arrives for an on the spot arrest:

They arrest Sule's corpse

His left hand clutching

A rumpled three kobo load. (SMP 18)

A glance at other poems in the same collection confirms that the poet often adheres to ordinary modes of speech comprising locutions in everyday use, at times of multi-lingual coinage (for instance in "Sule Chase", "olee barawoooooo onyeoshiiiii", is commonly employed in the Yoruba, Hausa and Igbo languages among ordinary people to indicate the presence of a thief). Osundare does employ the ordinary language of man here. But one can also point out the inclination of the poet to luxuriate in verbal extravagance such as the parallel "mountains/of fresh assorted garbage" and the highly metaphorical "valleys/of liquefied stench". In both cases, the use of geographical imagery arguably moves the poem from "the real language of men" towards another, poetic, plane.

The aim of this paper has been to investigate the dialogue between Romantic and postcolonial theory through a case in point, notably to discuss the extent to which the poetic praxis of a Nigerian poet in an African setting such as Osundare may be considered analogous to the Wordsworthian doctrine of simple subjects and simple diction. No Nigerian poet is more emphatically the poet of rusticity, judging from his preoccupation with humble people ranging from rural farmers and domestic workers to prostitutes and petty thieves. While Osundare exhibits the common people of Nigeria much more than any other poet and makes a point of deploying the "plainer and more emphatic language," desired by Wordsworth, or "the real language of men," he can be astonishingly daring with language and imagery, at the risk of being obscure. Nonetheless, even outside of all considerations of filiation, one can make a parallel between the Romantic reaction to neoclassicism and the postcolonial (and also postmodern) reactions to European and American high modernism, seeing as both postcolonialism and postmodernism are both grounded in the concern with the ex-centric.

Kola EKE

University of Benin, Nigeria 


\section{Works Cited}

Bamikunle, Aderemi. "The Development of Osundare's Poetry: A Survey of Themes and Technique". Research in African Literatures 26.4 (1995): 121-137.

Chinweizu, et al. Toward the Decolonization of African Literature. Enugu: Fourth Dimension, 1980.

Diyanni, Robert and Kraft Rompf. TheMcGraw-Hill Book of Poetry. New York: McGrawHill, 1993.

JeYIFo, Biodun. "Niyi Osundare". Perspectives on Nigerian Literature: 1700 to the Present. Vol. 11 Ed. Yemi Ogunbiyi. Lagos: Guardian, 1988. 314-320.

Ngara, Emmanuel. Ideology and Form in African Poetry. London: James Currey, 1990.

Osundare, Niyi. Songs of the Market Place. Ibadan: New Horn, 1983.

-. Village Voices. Ibadan: Evans Brothers, 1984.

-. A Nib in the Pond. Ibadan: Evans Brothers, 1986.

-. The Eye of the Earth. Ibadan: Heinemann, 1986.

-. Songs of the Season. Ibadan: Heinemann, 1990.

Pope, Alexander. "Essay on Criticism". Literary Criticism of Alexander Pope. Ed. Bertrand. A. Goldgar. Lincoln: Nebraska Press, 1965. 10-22.

Wordsworth, William. "Preface". Lyrical Ballads. Ed. R.L. Brett and A.R. Jones. Cambridge: Univ. Press, 1963. 241-272. 